\title{
Does Teacher Availability Matter? Evidence from Uwezo East Africa Study Data
}

\author{
By \\ Ishmael I. Munene, PhD (Corresponding Author) \\ Associate Professor \\ Educational Leadership Dept. \\ College of Education \\ Northern Arizona University \\ Ishmael.Munene@nau.edu \\ And \\ Sara J. Ruto, PhD \\ Director \\ PAL Network Secretariat \\ sruto@palnetwork.org
}

\begin{abstract}
Student academic achievement is a confluence of many variables. Among the most debated is the impact of teachers on students' overall academic success. Teacher characteristics that have impact on students' achievement include academic and professional training, self-efficacy, incentive systems and class attendance. The current study presents findings on the relationship between teacher variables and primary school students' achievement in literacy and numeracy skills derived from Uwezo survey data in Kenya, Tanzania and Uganda. Using chi-square correlation coefficient, the study established significant positive correlation between head teacher experience as well as teacher class attendance and student achievement in literacy and numeracy skills in the three countries. The study recommends the strengthening of professional conditions and an incentive structure for teachers so as to improve and reinforce their continued stay in the school in order to enhance students' learning outcomes.
\end{abstract}

\section{Introduction}

Of the many variables that impact students' academic achievement, none has elicited as much attention and controversy as teachers. Policy makers, school administrators and parents regard teacher quality and quantity as central to improved students' performance although research data is inconsistent. Kane (2013) in a three-year study involving 3,000 teachers and their students in the United States established that teacher quality directly affects students' test score notwithstanding a student's prior test performance, a finding consistent with Rockoff (2004). Other studies have provided contrary evidence (Fehrler, Michaelowa, \& Wechtler, 2009; Hanushek, 1986; 2003). This has raised important policy questions as to which teacher characteristics are important and which are not in determining students scholastic achievement (Goe \& Stickler, 2008).

Journal of Contemporary Issues in Education, 2015, 10(1), pp . 46-60

ISSN 1718-4770 (C) 2015 University of British Columbia/University of Alberta

http://ejournals.library.ualberta.ca/index.php/JCIE 
Student achievement has become an important public policy issue in recent years owing to concerns over student achievement following the launch of Education for All (EFA) programs particularly in developing countries. With the admission of more students, previously denied access due largely to economic factors, and without requisite increase in the quantity and quality of teachers, there has been a notable decline in student achievement as measured by test scores as the case in Africa demonstrates (UNESCO, 2012, pp. 3-4; Teachers for EFA, 2011). The centrality of teacher variable in educational achievement within the African context cannot be gainsaid. Due to high levels of household poverty coupled with dismal library and other educational resources in schools, teachers are the most critical resource in ensuring learning. Even though there is consensus on the significance of teacher variable in student academic attainment in Africa, there is minimal research on which dimensions of teacher variable are important especially with the advent of EFA programs.

Since the 1990 World Conference on Education for All (WCEFA) held in Jomtien, Thailand, African countries have embarked on universal primary education programs aimed at ensuring access and retention of all eligible children in primary school. In East Africa, Uganda was the first to launch the Universal Primary Education (UPE) program in 1997 followed by Tanzania's renewed commitment to universal primary education through a five-year Primary Education Development Plan (PEDP) in 2000. Kenya was the last nation to enact a UPE program but did so in 2003 when it launched the Free Primary Education (FPE) which sought to ensure all eligible primary school children were enrolled in schools. Through these programs, student enrollment in public schools has increased dramatically. However, their academic performance has registered a decline and many students lack mastery of literacy and numeracy skills expected of their grade levels (Uwezo, 2012).

In the face of increased student enrollment and accompanying decline in academic achievement, important questions about the impact of teachers must be raised. Using the Uwezo data, this article presents findings on the influence of selected teacher characteristics on student achievement in literacy and numeracy skills in the three East African countries of Kenya, Tanzania and Uganda in 2012. Uwezo was founded by Twaweza--an independent East African initiative that promotes information access, citizen agency and improved service delivery--in 2009 with the expressed goal of generating public data on quality of education across the three East African countries.

\section{Teacher Characteristics \& Student Achievement: Research Evidence}

Student achievement has been a subject of intense research in recent times (Fehrler, Michaelowa, and Waechtler, 2009; Glewwe \& Kremmer, 2006; Michaelowa, 2002). Research findings suggest that students' socio-economic background, school facilities and teacher quality in terms of quality and availability are the most significant determinants of achievement. Aspects of teacher characteristics that are germane to student achievement include qualification and training, efficacy, absence and time use in the classroom. Goe and Stickler (2008) aver that teacher credentials, knowledge and experiences constitute the totality of teacher qualifications that determine, to a considerable degree, student learning outcomes.

Journal of Contemporary Issues in Education, 2015, 10(1), pp. 46-60 ISSN 1718-4770 (C) 2015 University of British Columbia/University of Alberta http://ejournals.library.ualberta.ca/index.php/JCIE 
Of the many teacher attributes that have a bearing on student learning outcomes, academic qualifications and professional preparation rank among the top (Dodeen, Abdelfattah, Shumrani, $\&$ Hilal, 2012). They are also among the most investigated. Teacher qualifications refer to credentials, knowledge and experiences that a teacher brings to bear in the performance of their job. A large body of studies has established a positive correlation between professional teacher qualifications and student achievement. Teachers with higher academic achievement coupled with good professional training register higher student achievement (Dodeen et al., 2012; Goe, 2007; Nye, Konstantopoulos, \& Hedges, 2004; Wenglinsky, 2002; Cohen \& Hill, 2000; Goldhaber \& Brewer, 1997). A corollary evidence has been that teachers with low academic preparation or inferior professional preparation register decreased student academic achievement. In a comparative study, Dodeen et al. (2012) observed that because of superior academic achievement along with professional training Taiwanese teachers produced better student achievement in mathematics than their Saudi Arabian counterparts who had lower academic credentials and professional training.

While educational credentials and professional training are important in determining student achievement, there are important caveats. In the PASEC (Programme for the Analysis of Education Systems) group of countries in Africa, research suggests that teacher educational attainment and professional training is not statistically significant at 5\% level in accounting for $2^{\text {nd }}$ and $5^{\text {th }}$ grade literacy and mathematics scores (Bonnet, 2007). However, for the Southern and Eastern African Consortium for Monitoring Educational Quality (SACMEQ) countries, academic qualifications and professional training registers significant correlation (Fehrler et al., 2009). It would appear that regional context is important in determining the impact of these teacher variables on student achievement. Furthermore, there is also evidence to suggest that professional development through in-service training is negatively correlated to student achievement; such training takes away valuable instructional time from the students (Nguyen et al., 2005)..

Another important teacher variable that research has shown to impact student achievement teacher is incentive. Teacher incentives encompass a gamut of attributes but the most cited include monetary rewards, small class size and student role in evaluation of teachers. Monetary incentives are the most preferred means of motivating teachers to enhance student achievement. Studies show that additional monetary rewards results in improved teacher performance and subsequently student achievement; the magnitude is greater for students from lower socioeconomic status (Figilio \& Kenny, 2007; Podgursky \& Springer, 2007). However, other studies suggest the contrary; merit pay as an incentive is counterproductive as it leads to competition, jealousy and cheating among teachers (Malen, 1999). Other studies have documented the absence of significant correlation between incentive pay on improved teacher-student relationship and academic achievement (Barile et al., 2012).

Whereas research highlights the statistical significance of positive teacher-student relationship to student academic achievement (O'Connor \& McCartney, 2007; Lee \& Burkam, 2003; Muller, Katz, \& Dance, 1999), it does also show that monetary incentives to teachers and large school size are negatively correlated to a positive teacher-student relationship (Barile et al., 2012). Teachers contribute towards a positive teacher-student relationship when they show awareness

Journal of Contemporary Issues in Education, 2015, 10(1), pp. 46-60 ISSN 1718-4770 (C) 2015 University of British Columbia/University of Alberta http://ejournals.library.ualberta.ca/index.php/JCIE 
and concern for students' emotional well-being (Curby, Rimm-Kaufman, \& Ponitz, 2009; Hamre et al., 2006; Gest, Welsh, \& Domitrovich, 2005; Pianta \& Stuhlman, 1992; Furrer \& Skinner, 2003). A related construct is teacher attitude. Teachers with positive attitude towards student success and towards their own work are more likely to impact student achievement in a positive manner (Gbore \& Daramola, 2013). In addition, school policies providing for student evaluation of teachers contributes to improved teacher-student relationship.

Teacher professional identity, research suggests, also has an important impact on student achievement. Professional identity in this instance includes job satisfaction, occupational commitment, self-efficacy and level of motivation. It pertains to how teachers view themselves as teachers and is informed by their interaction with context. The interaction manifests itself in job satisfaction, occupational commitment, self-efficacy and change in the level of motivation. Research indicates that teacher classroom efficacy is strengthened by increasing teacher professional identity (Canrinus et al., 2012). In turn, this contributes to students' academic achievement.

A final consideration pertinent to this review is teacher gender. Students taught by female teachers tend to score higher than their male counterparts in standardized tests. Furthermore, girls showed better performance in all areas but were exceptional in languages (Burusic, Babarovic, \& Seric, 2012). These findings suggest that female teachers are more successful than their male counterparts. Since teaching is largely considered a female occupation, male teacher are confronted with hostilities and prejudices that they are perceived as performing female tasks. This concise review of literature on teacher variables and student academic achievement provides a basis for interpreting the data collected on teachers in the Uwezo regional survey. The next section will consider how this data was collected, followed by an analysis of the data.

\section{Methodology}

The core purpose of Uwezo surveys is to generate robust and nationally representative data. Using the approach first developed in India by the Assessment Survey Evaluation Research Center (ASER), Uwezo utilizes large scale household and school characteristic surveys. In order to generate a representative sample, the surveys employ a three stage random sampling design. The first stage entails the selection of districts by simple random sampling with each district given an equal probability of selection. The second stage involves the selection of around 30 primary sampling units (PSUs, typically villages, popularly referred to as enumeration centers) per district with probability proportional to population size. The third stage is the selection of around 20 household in each enumeration area by systematic sampling. Because the design is provided by each country's national statistical agency based on population census frames, it ensures that the surveys are representative at the national and district levels for all the children at school. The sampling strategy yielded 350,000 children, over 150,000 households and more than 6,000 individual schools in the three countries combined. This translates into $75 \%$ of all Kenyan districts, $100 \%$ of all Tanzanian districts and all but one district in Uganda.

Each PSU data collection involves a three step procedure. The first is to survey the local government primary school, randomly pre-selected. In the school data is collected through direct 
observation of pupil and teacher attendance numbers as well as the school conditions according to a simple questionnaire (such as teacher qualifications and attendance). Students are tested on literacy and numeracy skills appropriate for the grade level. In literacy, writing and reading in English and Kiswahili is tested. In the second stage, the administrative head of the PSU (village) along with confirming the validity of the sample was asked a series of simple questions according to a simple questionnaire (such as access to school, water and health services). In the third stage, the head of each household was interviewed on items in a simple questionnaire including details of their children (such as age, gender and whether or not attending school).

The data gathering instruments were reviewed by a team of experts comprising of Uwezo staff and consultant researchers from local universities in the three regions. Once they were approved, they were piloted in a sample of districts to ensure they were appropriate in language, length and issues to be studied. Afterwards revisions were made before the collection of data was undertaken. Data collection activities utilized local community groups. Volunteers were identified within local groups, trained by Uwezo research staff on how to collect field data. Not only did this keep the costs low while allowing data collection on a large scale than would otherwise have been possible, it also promoted the involvement of local citizens as well as the cultural credibility of the survey assistants.

Prior to analysis, data cleaning was undertaken in order to (a) remove information that could lead to identification of individuals, schools or villages, (b) ensure a minimum degree of consistency between datasets across the three countries over time, (c) remove observations that are redundant or manifestly problematic, (d) address missing test score data in a simple and transparent manner, and (e) facilitate analysis of the datasets (individually or in conjunction) by end users. The cleaning processes involved (a) establishing a "clean" set of geographical identification variables for each country, (b) ensuring that each household, school and village datasets can be correctly and simply "joined", (c) renaming and labeling core variables that are common to each dataset, (d) creating consistent categorical/numerical codes for common variables where possible, (e) dropping observations that do not have a minimum amount of usable information (e.g. no age), (f) ensuring consistency across school-level information (e.g. some enrolled in school cannot simultaneously have dropped out), (g) calculating sample weights, and (h) imputing missing test scores via a multiple regression procedure. Descriptive statistics were used to analyze the final data to generate the regional and country reports.

In order to explore the relationship between teacher variables and student learning outcomes, a chi-square correlation coefficient was undertaken between the pertinent teacher characteristics and students test scores. A chi-square correlation coefficient was selected because of the data was nominal/categorical and non-parametric. For groups of students in a class, we used various levels of competence in literacy and numeracy skill with the lowest value being no competence (unable to answer) and the highest value being full competence (pass the test). The categories for head teachers years of experience included: minimally experienced (1-3 years), moderately experience (3-7 years), very experienced (8-15 years) and highly experienced (over 15 years). As for teacher attendance rate, four categories were also identified: always absent, moderately absent, frequently present and always present.

Journal of Contemporary Issues in Education, 2015, 10(1), pp. 46-60 ISSN 1718-4770 (C) 2015 University of British Columbia/University of Alberta http://ejournals.library.ualberta.ca/index.php/JCIE 


\section{Key Findings}

\section{Results for Literacy and Numeracy Tests}

Generally, the data painted a picture of poor performance in the key areas of literacy and numeracy. Very few students enrolled in standard (grade) 3 can pass any of the individual tests. In more precise terms, less than one in three children were able to pass the Kiswahili (32\%) and numeracy tests (29\%), but only one in six passed the English test (16\%). In a similar vein, less than one in six was able to pass the literacy and numeracy tests combined (15\%). The results imply failure by the majority of students to acquire basic learning competencies in the early years of their schooling.

The key performance indicators of students in the three East African countries are disclosed in Figure 1 which plots the percentage of children aged 10 and 16 that are able to pass each of the individual tests (English, Kiswahili and numeracy) alongside the main literacy and numeracy tests combined. There are significant differences across the three countries with regard to literacy and numeracy skills. On the whole, the data shows that Kenyan children outperform children from the other two countries in all test areas. Kenya's outstanding performance in English is obvious, twice that of Tanzanian students (39\% higher) and 29\% higher than in Uganda. Even in Kiswahili which is the national language in Tanzania, Kenyan students outperform their Tanzanian counterparts by $20 \%$ points (Uganda does not teach Kiswahili). The smallest percentage of differences is in numeracy but even here, Kenya outperforms the other countries.

Suffice to note that better performance by Kenyan students is only relative. Only one third of the pupils in standard 3 in the country (fewer in Tanzania and Uganda) can pass standard 2 level tests. Furthermore while data suggests that Ugandan students are the worst performers, at upper grades they do play "catch up" and at standard 6, they slightly outperform their Tanzanian counterparts.

\section{Results for Teacher Characteristics}

Table 2 summarizes data on pupil-teacher ratio as well as teacher class attendance. The average class size was in Kenya's (Ke) favor with a class size of 29 and an observed pupil-teacher ratio of 38. Tanzania (Tz) and Uganda (Ug) had larger but relatively similar class sizes of 40 and 49 and observed pupil-teacher ratios of 36 and 61 respectively. In addition, Kenya had a better teacher attendance rate than both Tanzania and Uganda. On the whole, Kenya seems to fare better than its neighbors in terms of all the variables related to class size, pupil-teacher ratio and class attendance.

Notwithstanding the inter-country differences, the data also reveals important intra-country distinctions. In Kenya, the central region has the smallest class size while the highest is found in the western part of the country. In Tanzania, Shinyanga region has the largest class size while Arusha the smallest. In Uganda the northern region registers the largest class size while the central region has the smallest. Another notable observation is that Uganda presents the largest discrepancy between the formal (reported) and the observed pupil-teacher ratio with the eastern and northern regions differences being especially revealing. The running narrative in these 
differences in class sizes is that the more affluent regions - those with a higher economic basehave smaller class sizes than their less economically endowed counterparts.

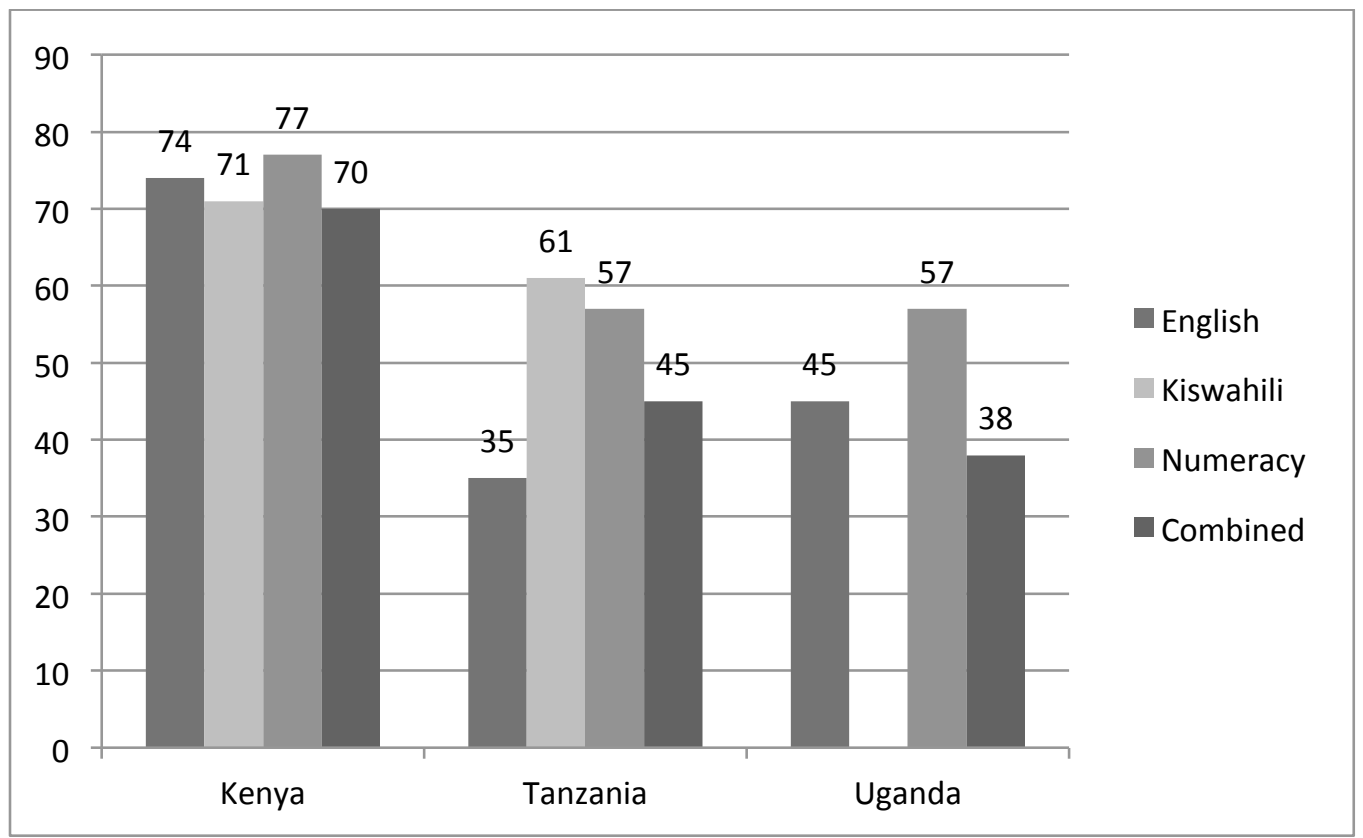

Figure 1: Test Pass Rates for Children Aged 10-16, by Country 
Table 1: Pupil-Teacher Ratio and Teacher Class Attendance Rate

\begin{tabular}{|c|c|c|c|c|c|}
\hline \multirow[b]{2}{*}{ Country } & \multirow[b]{2}{*}{ Region } & \multirow[b]{2}{*}{ Class size } & \multicolumn{2}{|c|}{ Pupil/Teacher ratio } & \multirow{2}{*}{$\begin{array}{c}\text { Attend } \\
\text { rate }\end{array}$} \\
\hline & & & Formal & Observed & \\
\hline $\mathrm{Ke}$ & Central & 26.1 & 28.5 & 29.8 & 90.3 \\
\hline $\mathrm{Ke}$ & Coast & 33.3 & 40.7 & 36.6 & 88.4 \\
\hline $\mathrm{Ke}$ & Eastern & 27.8 & 30.2 & 28.7 & 89.7 \\
\hline $\mathrm{Ke}$ & North Eastern & 31.6 & 45.4 & 44.2 & 90.0 \\
\hline $\mathrm{Ke}$ & Nyanza & 28.2 & 31.6 & 29.9 & 87.6 \\
\hline $\mathrm{Ke}$ & Rift Valley & 27.1 & 29.9 & 29.4 & 87.4 \\
\hline $\mathrm{Ke}$ & Western & 40.4 & 40.7 & 37.9 & 89.3 \\
\hline $\mathrm{Ke}$ & TOTAL & 29.5 & 32.9 & 31.7 & 88.6 \\
\hline $\mathrm{Tz}$ & Arusha & 27.5 & 31.2 & 24.0 & 85.8 \\
\hline $\mathrm{Tz}$ & Dar es Salaam & 35.0 & 21.0 & 21.6 & 78.2 \\
\hline $\mathrm{Tz}$ & Dodoma & 43.9 & 48.2 & 42.5 & 80.2 \\
\hline $\mathrm{Tz}$ & Iringa & 36.5 & 31.1 & 35.6 & 93.3 \\
\hline $\mathrm{Tz}$ & Kagera & 45.5 & 46.8 & 43.5 & 85.2 \\
\hline $\mathrm{Tz}$ & Kigoma & 41.1 & 46.0 & 41.9 & 75.8 \\
\hline $\mathrm{Tz}$ & Kilimanjaro & 32.0 & 28.3 & 28.8 & 87.0 \\
\hline $\mathrm{Tz}$ & Lindi & 30.2 & 45.3 & 37.2 & 91.7 \\
\hline $\mathrm{Tz}$ & Manyara & 37.8 & 34.6 & 32.1 & 91.3 \\
\hline $\mathrm{Tz}$ & Mara & 50.7 & 50.8 & 41.1 & 87.6 \\
\hline $\mathrm{Tz}$ & Mbeya & 39.1 & 34.5 & 31.6 & 88.6 \\
\hline $\mathrm{Tz}$ & Morogoro & 40.6 & 37.2 & 35.1 & 78.4 \\
\hline $\mathrm{Tz}$ & Mtwara & 39.3 & 38.9 & 43.0 & 93.2 \\
\hline $\mathrm{Tz}$ & Mwanza & 39.3 & 34.5 & 29.5 & 89.1 \\
\hline $\mathrm{Tz}$ & Pwani & 36.6 & 37.6 & 35.8 & 77.3 \\
\hline $\mathrm{Tz}$ & Rukwa & 36.4 & 53.3 & 42.2 & 73.5 \\
\hline $\mathrm{Tz}$ & Ruvuma & 36.4 & 42.9 & 39.8 & 86.0 \\
\hline $\mathrm{Tz}$ & Shinyanga & 51.9 & 48.5 & 44.0 & 81.5 \\
\hline $\mathrm{Tz}$ & Singida & 42.1 & 32.9 & 40.9 & 82.7 \\
\hline $\mathrm{Tz}$ & Tabora & 48.0 & 47.9 & 40.7 & 79.3 \\
\hline $\mathrm{Tz}$ & Tanga & 41.4 & 39.9 & 36.3 & 82.6 \\
\hline $\mathrm{Tz}$ & TOTAL & 40.3 & 39.6 & 36.3 & 83.9 \\
\hline $\mathrm{Ug}$ & Central & 38.7 & 43.5 & 45.8 & 79.2 \\
\hline $\mathrm{Ug}$ & Eastern & 53.3 & 56.6 & 71.2 & 61.0 \\
\hline $\mathrm{Ug}$ & Nothern & 56.4 & 57.2 & 70.2 & 59.2 \\
\hline $\mathrm{Ug}$ & Western & 45.3 & 48.6 & 54.4 & 72.2 \\
\hline $\mathrm{Ug}$ & TOTAL & 48.5 & 51.6 & 60.7 & 67.8 \\
\hline
\end{tabular}


In terms of school leadership, the average number of years as head of the current school showed variations between both Kenya and Uganda on the one hand and Tanzania on the other. In Kenya and Uganda, the average years served as head of the current school were 3.4 and 3.6 years respectively. In Tanzania, the average was 7.3 years. So head teacher turnover was lower in Tanzania than in Kenya. As for the total number of years as a head teacher, the averages for the three countries were almost similar though Kenya and Tanzania were closer with 9.0 and 8.6 years respectively. Uganda had the highest score in this area with 11.5 years.

\section{Results for Teacher Characteristics and Learning Outcomes}

In this section, we provide the results of the correlation between the pertinent teacher characteristics and students learning outcomes. The teacher characteristics captured in the study were (1) head teachers experience, and (2) teacher classroom attendance rates. In the present investigation, we sought to establish the relationship between head teachers' years of experience and teacher attendance rate and student learning outcomes in both literacy and numeracy skills in the three East African countries. In Table 2, the results of the correlation between head teacher experience and students performance in math and literacy scores are disclosed. In all the three countries, there were significant positive correlations between the head teacher experience and students performance in maths and literacy tests. The results also indicate a minimal effect size as the Cramer's $V$ scale ranged from a low of 0.06 to a high of 0.12 . Thus we are confident that the results were not negatively impacted by the sample size.

Table 2: Relationship between Head Teacher Experience and Maths and Literacy Tests

\begin{tabular}{|l|c|c|c|c|c|c|}
\hline Country & Subject & Sample & Pearson Chi & df & $\boldsymbol{P}$ & Cramer's $V$ \\
\hline \multirow{3}{*}{ Kenya } & Maths & 2148 & 52.87 & 21 & $0.001^{*}$ & 0.09 \\
\cline { 2 - 7 } & Literacy & 2148 & 37.19 & 12 & $0.001^{*}$ & 0.07 \\
\hline \multirow{3}{*}{ Tanzania } & Maths & 2640 & 54.55 & 18 & $0.001^{*}$ & 0.08 \\
\cline { 2 - 7 } & Literacy & 2640 & 58.24 & 12 & $0.001^{*}$ & 0.08 \\
\hline \multirow{3}{*}{ Uganda } & Maths & 1412 & 62.56 & 18 & $0.001^{*}$ & 0.12 \\
\cline { 2 - 7 } & Literacy & 1412 & 17.22 & 12 & $0.001^{*}$ & 0.06 \\
\hline
\end{tabular}

As for teacher attendance rate, a similar significant correlation was obtained in all the three countries for both maths and literacy test scores. In Kenya, teacher attendance rate was positively correlated to maths score, $\mathrm{X}^{2}(21, \mathrm{~N}=8592)=60.25 p<.001$ as well as literacy scores $\mathrm{X}^{2}(12$, $\mathrm{N}=8592)=73.89 p<.001$. The same results were obtained in Tanzania where the maths scores

Journal of Contemporary Issues in Education, 2015, 10(1), pp. 46-60 
positively correlated with teacher attendance rate, $\mathrm{X}^{2}(18, \mathrm{~N}=10,560)=89.67 p<.001$ as was the case with literacy test scores, $\mathrm{X}^{2}(12, \mathrm{~N}=10,560)=51.20 p<.001$. Equally, the Ugandan results demonstrated a similar positive correlation for maths scores $\mathrm{X}^{2}(18, \mathrm{~N}=5648)=79.84 p<.001$ as well as for literacy scores, $\mathrm{X} 2(12, \mathrm{~N}=5648)=100.00 p<.001$. For all these scores, the effect size was minimal ranging from a low of 0.01 to a maximum of 0.40 on Cramer $V$ scale.

\section{Discussion}

Generally, the analysis of student learning outcomes data showed that student achievement in the basic learning competences in literacy and numeracy were at best disappointing. In most schools students were unable to read or perform mathematical calculations required for their grade level. While Kenyan students outperformed their counterparts in Tanzania and Uganda, this comparative data only serves to mask the equally low achievement trends of students in elementary schools. That performance in the key competence areas of maths and literacy are disappointingly low within the region suggests additional challenges in providing quality education in the higher levels of primary schools.

From the analysis of teacher data collected in the Uwezo learning outcomes data, teacher characteristics had a pronounced relationship with student learning outcomes as measured by maths and literacy test scores. Significant relationships were obtained between the head teachers years of work experience and students' score in maths and literacy in the three countries. Although our study did not examine exactly what principals do to enhance student learning outcome, this finding is consistent with studies that have documented the importance of the principal in enhancing academic achievement (Stronge, Richard, \& Catano, 2008; Brewer, 1993; Eberts \& Stone, 1988). As instructional leaders in the school, principals provide a critical role in gathering crucial information about the curriculum, are cognizant of the best practices in teaching, mobilize resources needed for teachers to succeed and also counsel teachers on best practices. They also actively participate in staff development programs and also contribute to conflict resolution programs. Therefore, the more years of experience a principal has attained on the job, the more he/she is able to successfully accomplish these tasks. This then translates into improved students' academic achievement.

Teacher school attendance rate was significantly associated with learning outcomes in maths and literacy in all the three countries. The more times the teachers were in school, the higher the students registered in academic achievement. Since teacher attendance is of such crucial significance, the onus is to identify the particular teacher characteristics that increase attendance and teacher classroom behaviors that are central to the achievement. Teachers with a high sense of professional identity also display increased occupational commitment, self-efficacy and motivation which lead to improved student academic achievement (Canrinus et al., 2012). Further, this finding buttresses the importance of positive teacher-student relationship. This relationship is nurtured and enhanced by constant teacher presence in the classroom and translates into improved student learning outcomes (O'Connor \& McCartney, 2007; Lee \& Burkam, 2003). Regular teacher attendance is also connected to the concern for the emotional wellbeing of students leading to improvement learning (Curby et al., 2009; Hamre et al., 2006).

Journal of Contemporary Issues in Education, 2015, 10(1), pp. 46-60 


\section{Conclusion}

This analysis sought to extrapolate Uwezo teacher data and correlate them to student learning outcome. The data highlighted the low achievement rates in maths and literacy by students from grade 1 to 3. Most students performed below their grade level. The study also documented the highly significant positive relationship between primary school principals' experience and students learning outcomes. In addition, the analysis revealed the highly significant positive correlation between teacher school attendance rate and student learning outcomes.

One important implication of these findings is that improvement in teacher job-related conditions is paramount to improved student learning outcomes. Since poverty precludes the possibility of the home environment providing the requisite conditions for improved students' performance, the teacher will continue to be the main fulcrum upon which improvement in student learning outcome will be hinged upon. Therefore, experienced principals could be a good solution to underperforming schools. For newly appointed principals, stability of tenure in one school could provide them with the learning experience needed to successfully navigate the intricacies of being an instructional leader in addition to the managerial role. The findings also suggest the need for opportunities for staff development for school principals. As instructional leaders in the schools, principals need modern skills in curriculum implementation and teacher management. Therefore, local universities with educational programs need to find a way of disseminating current practical information to schools and classrooms.

Another important implication of the analysis is the need to improved teacher incentives for work. Teacher-incentives are related to feelings of being appreciated, heightened self-worth, and improved job satisfaction. All these translate into increased teacher attendance to school and classroom. Attendance to school and classroom translate into a synergistic teacher-student relationship leading to improved learning outcomes. So the onus is on east African governments, who are the main employers of public school teachers, to provide incentives that promote teachers' positive view of their career. Among these are improved compensation and opportunities for training and career growth.

This study only examined limited aspects of teacher characteristics. It is therefore important that additional studies be undertaken in the region to validate these findings. In particular, there is a need to additional investigation of the impact of head teacher characteristics on student achievement. The actual process through which head teachers inspire and mentor teachers leading to the latters' improved self-efficacy and subsequent improvement in student achievement is a fertile area of investigation. Qualitative research studies using a multi-site case design will provide findings on the process and context of head teacher-teacher relationships and their impact on student academic achievement. Such detailed data is credible and usable by policy makers. There is also a need to explore the potential impact of teacher incentive structures in improving student learning outcomes. Are extrinsic performance-based pay structures the best for improving student learning outcomes? Many countries have attempted pay-for-performance as a strategy for enhancing accountability and student achievement. This has not been attempted in East Africa. It would be illuminating to understand teachers' perspectives on the issue.

Journal of Contemporary Issues in Education, 2015, 10(1), pp. 46-60 ISSN 1718-4770 (C) 2015 University of British Columbia/University of Alberta http://ejournals.library.ualberta.ca/index.php/JCIE 


\section{References}

Barile et al., J. (2012). Teacher-student relationship climate and school outcomes: Implications for educational policy initiatives. Journal of Youth Adolescence, 41, 256-267.

Bonnet, G. (2007). What do recent evaluations tell us about the state of teachers in Sub-Saharan Africa? Paris: UNESCO.

Brewer, D. (1993). Principals and student outcomes: Evidence from U.S. high schools. Economics of Education Review, 12(4), 281-292.

Burusic, J., Babarovic, T., \& Seric, M. (2012). Differences in elementary school achievement between girls and boys: Does the teacher gender play a role? Europoean Journal of Psychology in Education, 27(4), 523-538.

Canrinus, E. T., Helms-Lorenz, M., Beijaard, D., Buitink, J., \& Hofman, A. (2012). Selfefficacy, job satisfaction, motivation and commitment: Exploring the relationships between indicators of teachers professional identity. European Journal of Psychological Education, 27(1), 115-132.

Cohen, M., \& Hill, H. (2000). Instructional policy and classroom performance: The mathematics reform in California. Teacher's College Record, 10(2), 294-343.

Curby, T. W., Rimm-Kaufman, S. E., \& Ponitz, C. C. (2009). Teacher-child interactions and children's achievement trajectories across Kindergarten and first grade. Journal of Educational Psychology, 101(4), 912 - 925.

Dodeen, H., Abdelfattah, F., Shumrani, S., \& Hilal, M. A. (2012). The effects of teachers qualifications, practices, and perceptions on student achievement in TIMSS mathematics: A comparison of two Countries. International Journal of Testing, 12(1), 61-77.

Eberts, R., \& Stone, J. (1988). Student achievement in public schools: Do principals make a difference. Economics of Education Review, 7(3), 291-299.

Fehrler, S., Michaelowa, K., \& Waechtler, A. (2009). The effectiveness of inputs in primary education: Insights from recent surveys for sub-Saharan Africa. Journal of Development Studies, 25(9), 1545-1578.

Figilio, D., \& Kenny, L. (2007). Individual teacher incentives and student performance. Journal of Public Economics, 91, 901-914. 
Furrer, C., \& Skinner, E. (2003). Sense of relatedness as a factor in children's academic engagement and performance. Journal of Educational Psychology, 95(1), 148-162.

Gbore, L.,O., \& Daramola, C. A. (2013). Relative contributions of selected teachers' variables and students' attitudes towards academic achievement in biology among senior secondary school students in Ondo State, Nigeria. Current Issues in Education, 16(1), 1-10.

Gest, S. D., Welsh, J. A., \& Domitrovich, C. E. (2005). Behavioral predictors of changes in social relatedness and liking school in elementary school. Journal of School Psychology, 43(4), 281-301.

Glewwe, P., \& Kremer, M. (2006). Schools, teachers and educational outcomes in developing countries. In E. \&. Hanushek, Handbook of the Economics of Education, Vol. 2 (pp. 945 - 1012). Amsterdam: North Holland.

Goe, L. (2007). The link between teacher quality and student outcomes: A research synthesis. Washington, DC: National Comprehensive Center for Teacher Quality. Available at http://www.gtlcenter.org/sites/default/files/docs/LinkBetweenTQandStudentOutcomes.pdf

Goe, L., \& Stickler, L. (2008, March). Teacher quality and student achievement: Making the most of recent research. TQ Research and Policy Brief. Washington, DC: National Comprehensive Center for Teacher Quality. Available from http://www.gtlcenter.org/sites/default/files/docs/March2008Brief.pdf Retrieved 6/11/203.

Goldhaber, D., \& Brewer, D. (1997). Evaluating the effect of teacher degree on educational performance. In W. Fowler (Ed.). Developments in school finance (pp. 197 - 210). Washington, DC: NCES.

Hamre, B., et al. (2006). Social resources in the classroom and young children's academic and social development. Applying Prevention Research to Reduce Health Disparities. San Antonio, Texas: Society for Prevention Research.

Hanushek, E. (2003). The failure of input-based schooling policies. Economic Journal, 113(485), F64 - F98.

Hanushek, E. (1986). The economics of schooling: Production and efficiency in public schools. Journal of Economic Literature, 24(3), 1141 - 1177.

Kane, T. J., et al. (2013, June 10). Ensuring fair and reliable measures of effective teaching: Culminating findings from the MET's three year study. Bill \& Melinda Gates Foundation. Available at http://www.edweek.org/media/17teach-met1.pdf

Journal of Contemporary Issues in Education, 2015, 10(1), pp. 46-60 ISSN 1718-4770 (C) 2015 University of British Columbia/University of Alberta http://ejournals.library.ualberta.ca/index.php/JCIE 
Lee, V., \& Burkam, D. (2003). Dropping out of high school: The role of school organizational structure. American Educational Research Journal, 40, 353-393.

Malen, B. (1999). On rewards, punishments, and possibilities: Teacher compensation as an instrument for education reform. Journal of Personnel Evaluation in Education, 12, 387-394.

Michaelowa, K. (2002). Teacher job satisfaction, student achievement and the cost of primary education in francophone sub-Saharan Africa. HWWA Discussion Paper. Hamburg: Hamburg Institute of International Economics.

Muller, C., Katz, S. R., \& Dance, L. J. (1999). Investing in teaching and learning: Dynamics of teacher-student relationship from aach Actor's Perspective. Urban Education, 34, 292-337.

Nguyen, K., Wu, M., \& Gillis, S. (2005). Factors influencing pupil achievement in Sacmeq2Botswana: An application of structural equation modelling. International Innovational Educational Policy Research Conference. Paris: IIEP/UNESCO.

Nye, B., Konstantopoulos, S., \& Hedges , L. V.. (2004). How large are teacher effects? Educational Policy Analysis, 26(3), 237-257.

O'Connor, E., \& McCartney, K. (2007). Examining teacher-child relationships and achievement as part of an ecological model of development. American Educational Research Journal, 44, 340 -369 .

Pianta, R., \& Stuhlman, M. (1992). Teacher-child relationships and the process of adjusting to school. New Directions for Child Development, 57, 61-80.

Podgursky, M., \& Springer, M. (2007). Teacher performance pay: A review. Policy Retrospectives, 26, 909-940.

Rockoff, J. (2004). The impact of individual teachers on student achievement: Evidence from panel data. The American Economic Review, 94(2), 247-252.

Stronge, J., Richard, H., \& Catano, N. (2008). Qualities of effective principals. Alexandria, VA: Association for Supervision and Curriculum Development.

Teachers for EFA. (2011). Communique of the International Conference on Teachers for EFA in Africa: Collaborative action to address the teacher gap. Nairobi, January 19-20: Teachers for EFA.

UNESCO. (2012). EFA Global Monitoring Report 2012. Paris: UNESCO.

Uwezo. (2012). Are our children learning: Literacy and numeracy accross East Africa. Nairobi: Uwezo East Africa at Twaweza.

Journal of Contemporary Issues in Education, 2015, 10(1), pp. 46-60 
Wenglinksky, H. (2002). The link between teacher classroom practices and student academic performance. Educational Policy Analysis Archives, 10(12), 1-30. 